\title{
The Hummingbird sign: a diagnostic clue for Steele- Richardson-Olszweski syndrome
}

\author{
Nikhil Sonthalia, Sayantan Ray \\ Department of General Medicine, Medical College and Hospital, Kolkata, West Bengal, India
}

Correpondence to Dr Nikhil Sonthalia, nikhil_zenith@yahoo.co.in

\section{DESCRIPTION}

Progressive supranuclear palsy (PSP), previously known as Steele-Richardson-Olszweski syndrome, is an atypical parkinsonian syndrome with a prevalence of $\sim 5 / 100000$. It is an important differential diagnosis of more common idiopathic Parkinson's disease (iPD), where clinical differentiation is not straightforward and characteristic neuroimaging often yields a diagnostic clue. We describe a case of 75-year-old man with a history of slowness of activities and recurrent fall while walking, which was insidious in onset and gradually progressive for last 2 years. There was no history of tremor, stooping postures, urinary incontinence or hallucination. On examination supranuclear vertical gaze palsy with slow horizontal saccades, axial rigidity and bradykinesia were present. He had a slow gait with lack of associated movements and tendency to fall backwards. He had positive 'dirty tie sign' while eating. The patient was diagnosed as a probable case of PSP and MRI of the brain was done. Mid-sagittal T2-weighted MRI

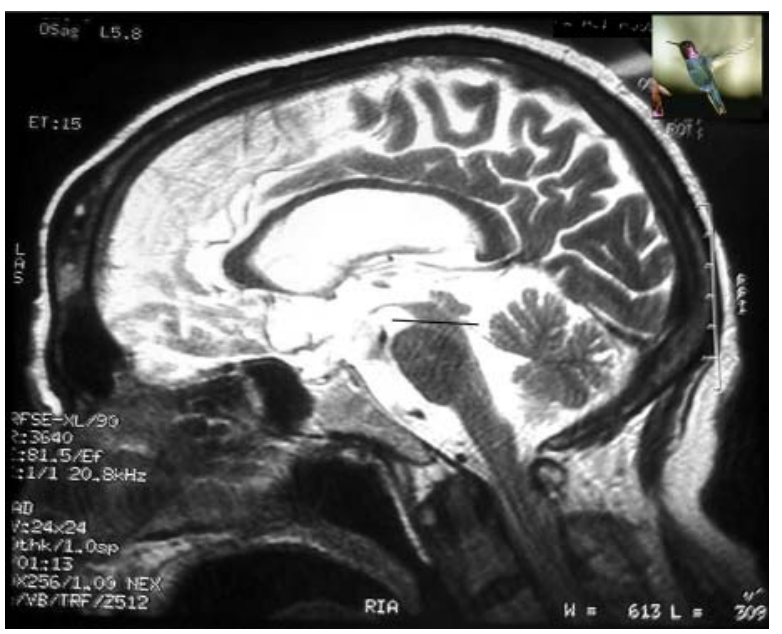

Figure 1 T2-weighted MRI image of the brain showing the selective atrophy of midbrain with preservation of pons (divided by the black line). The atrophy of the midbrain tegmentum results in the concavity forming the silhouette of the head of the 'Hummingbird' or the 'King Penguin' (inset). This feature is called the hummingbird sign. of the brain revealed characteristic selective atrophy of midbrain tegmentum (mesencephalon), with relatively preserved pons, giving an appearance of the head and body, respectively, of a hummingbird (figure 1). This is known as 'The Hummingbird sign' or 'The King Penguin sign'. ${ }^{1}$ The axial T2 MRI image shows a reduction in the anterior-posterior diameter of midbrain with thinning of cerebral peduncle giving appearance of 'morning glory sign' or the 'Mickey mouse sign' (figure 2). The hummingbird sign is reported to have a sensitivity of nearly $100 \%{ }^{1}$

Patients with iPD, multisystem atrophy (MSA), corticobasal degeneration do not have midbrain atrophy, thus making this sign important in differentiating these conditions from PSP. This sign also suggests rostral interstitial nucleus of medial longitudinal fasciculus involvement in $\mathrm{PSP}^{2} \mathrm{MR}$ parkinsonism index, defined as the ratio of midbrain area to pons area, is another useful tool in the diagnosis of PSP patients. ${ }^{3}$ The objective of this article is to highlight the importance of neuroimaging in working up of the differential diagnosis of closely related parkinsonian disorders such as iPD, MSA and PSP.

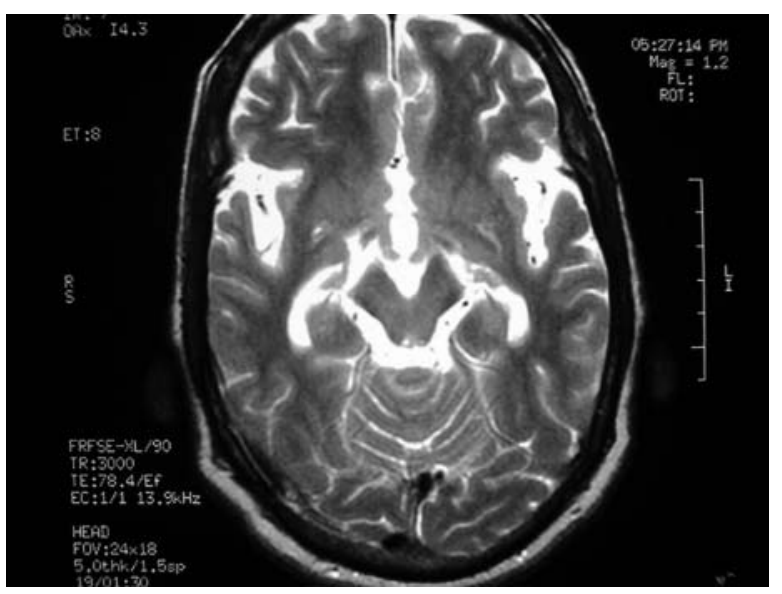

Figure 2 An axial T2-weighted image shows the atrophy of the midbrain tegmentum with thinning of cerebral peduncles resulting in the concavity at the lateral margin of the midbrain referred to as the 'Mickey mouse sign,' again characteristic of progressive supranuclear palsy. 


\section{BMJ Case Reports}

\section{Learning points}

- Progressive supranuclear palsy (PSP) is a so-called taupathy with a very low prevalence which has many clinical features overlapping with the more common classical idiopathic Parkinson's disease and differentiation on clinical grounds is difficult.

- Significant midbrain atrophy with no pons atrophy has been referred to as 'the Hummingbird sign' or the 'Penguin Sign'. This sign is quite useful in differentiating PSP from idiopathic Parkinson's disease and multisystem atrophy. Other imaging findings in PSP that may be seen are elevated apparent diffusion coefficient in the putamen, globus pallidus and caudate nucleus.

- Abnormal superior profile of midbrain, maximal diameter of midbrain in mid-sagittal plane and MR parkinsonism index are some of the useful keys derived from MRI of the brain that helps in establishing the diagnosis of PSP.
Acknowledgements Dr. Subhasis Maitra, MD, Assistant Professor, department of General Medicine for his clinical guidance in this case.

\section{Competing interests None.}

Patient consent Obtained.

\section{REFERENCES}

1. Kato N, Arai K, Hattori T. Study of rostral midbrain atrophy in progressive supranuclear palsy. J Neurol Sci 2003;210:57-60.

2. Slowinski J, Imamura A, Uitti RJ, et al. MR imaging of brainstem atrophy in progressive supranuclear palsy. J Neurol 2008;255:37-44.

3. Berg D, Steinberger JD, Warren OC, et al. Milestones in magnetic resonance imaging and transcranial sonography of movement disorders. Mov Disord 2011;26:979-92.

This pdf has been created automatically from the final edited text and images.

Copyright 2012 BMJ Publishing Group. All rights reserved. For permission to reuse any of this content visit http://group.bmj.com/group/rights-licensing/permissions.

BMJ Case Report Fellows may re-use this article for personal use and teaching without any further permission.

Please cite this article as follows (you will need to access the article online to obtain the date of publication).

Sonthalia N, Ray S. The Hummingbird sign: a diagnostic clue for Steele-Richardson-Olszweski syndrome. BMJ Case Reports 2012;10.1136/bcr-2012-006263, Published XXX

Become a Fellow of BMJ Case Reports today and you can:

- Submit as many cases as you like

- Enjoy fast sympathetic peer review and rapid publication of accepted articles

- Access all the published articles

- Re-use any of the published material for personal use and teaching without further permission

For information on Institutional Fellowships contact consortiasales@bmjgroup.com

Visit casereports.bmj.com for more articles like this and to become a Fellow 